\title{
English Language Skills and Job Opportunities, Privileges, Personal Functions and E-Uses as Perceived by Seniors in Palestinian Universities
}

\author{
Omar Mustafa Abu-Humos \\ Al-Quds University - PO Box: 51000- Palestine \\ omarabuhumos@gmail.com
}

\begin{abstract}
The study aims to explore the role of foreign languages in making available the expected job opportunities in the Palestinian society, the expected privileges in the work place associated with it, the current and future personal uses and the current e-uses of the foreign languages. The subjects are senior English Department students at Palestinian universities. The research design adopts a survey methodology using a questionnaire to elicit their perceptions in that regard. The findings are ushering in multiple sectors in local economy demanding these skills led by NGOs, interpretation and translation and teaching the foreign language, privileges at the work place, multiple personal functions of the foreign language, and many e-uses pertaining to social media. Therefore, the study recommends to abolish the classical literary components of the language programs currently prevailing to be replaced with market place language skills, such as ESP ones, which focus on workplace related skills such as proposal writing, letter writing, emailing, research writing, negotiation skills, public relations language skills and oral communication skills.
\end{abstract}

Keywords: foreign language and job opportunities, language and work place, language and sustainable development, university language program, language program redesign.

\section{INTRODUCTION}

Globalization has transformed the world into a small village; as a result, the world economy is increasingly transcending the domestic boundaries requiring a medium of communication shared by everyone; international companies are constantly expanding overseas, dealing with clients from all over the world, a need that boosted foreign language learning especially the English language more intensely in developing countries. English language is considered to be the world's leading language for business and education. Moreover, education and economy are perceived by educators and economists as inextricably intertwined. Education improvements are challengingly related to their contribution to economic development in any given society; therefore, the changes that might result from this research on the English language program in the Palestinian universities are expected to reflect positively on society's prosperity and wellbeing.

This research paper attempts to reveal the English language seniors' expectations regarding job opportunities offered by such qualifications, and their perception of the English language role in equipping individuals with the skills that promote their status in the work place in terms of privileges it offers them, the personal functions, and finally the e-uses related to that language. However, the results of this study would be valuable for educators to assess the current undergraduate English language programs on which seniors are enrolled and adjust these programs in a way that meets the needs of the market place. The research design is used by employing a questionnaire which has been prepared for the purpose of collecting data from seniors in three English language departments in three Palestinian universities.

\section{REVIEW OF LITERATURE}

\subsection{Education For Sustainable Development (ESD)}

Sustainable development is "a development that meets the needs of the present, without compromising the ability of the future generations to meet their own needs" (Our Common Future 1987, p.41). However, it integrates three main manifold factors: environmental, social, and economic. Sustainable development aims to find better ways of doing things, both for future and the present. 
Sustainable development includes social factors in which education holds a significant position. Education in its general sense is defined as a form of learning in which the knowledge, skills, values, beliefs, and habits of a group of people are transferred from one generation to the next through storytelling, discussion, teaching, training, and/or research. Therefore, exploring foreign language learning in Palestine in relation to sustainable development is necessary for promoting development.

\subsection{Primary, Secondary, and Tertiary Education and Economic Growth}

The correlation between education and the growth of economy is quite apparent. Drawing on the experiences of the European Union and the United States of America, one can notice the educationinnovation link. In a study, Sapir (2003) shows that while the European Union has encountered slower economic growth because of its meager investments in higher education, $1.1 \%$ of its GDP, the United States of America witnessed faster growth because of its 3\% investment in the same domain. Moreover, Scherer and Hue (1992) show in their studies that "enterprises whose executives have a high level of technical education spend more money on research and development that lead to innovations". On the other hand, investing in primary and secondary education has its significant impact as well. The European Union's experience thirty years after the World War II shows how its investment in primary and secondary education had a great impact on its economic growth, even faster than the U.S. Similarly, the high productivity growth in Asian countries is associated with their investments in primary and secondary education rather than their investments in higher education. However, Krueger and Lindahl (2001) concluded that "overall education is statistically, significantly, and positively associated with subsequent growth only for the countries with the lowest education". Many economists believe in the correlation between education and growth. For example, For example, Nelson and Phelps (1966) argue that educated labor force are more successful in imitating technology, and the closer a state is to technology, the greater the benefits of its catch-up.

\subsection{Foreign Languages and Economic Growth}

The globalized economy continues to demand for English language proficiency. The English language skills are increasingly important in helping individuals succeed in their jobs, and businesses to reach out to international markets. Developing nations seek to reposition themselves in the new global economy by employing more strategies to achieve this goal; one of these strategies is underpinning individuals' language skills. This indicates how English language skills became a crucial requirement to develop a competitive economic advantage in the global economy. Hence, companies that aim to invest worldwide require their employees to speak English at the intermediate level at least. One study conducted by the Economist Intelligence Unit (2012) based on a survey targeted at 572 executives in Europe, Asia Pacific, North America, and Latin America reported that "even when recruiting for jobs in their home market, almost one-half of all companies say that prospective candidates need to be fluent in a foreign language, and a further $13 \%$ say that multilingual ability is a key selection criterion". Another study conducted by Robert Pinon and Jon Haydon (2010) on 42 companies in five countries: Bangladesh, Cameroon, Nigeria, Pakistan, and Rwanda affirms that English language skills are significantly demanded: "On average, over half of interviewees in the researched countries commented that their workforce was required to speak English to at least intermediate level"; moreover, "On average for all the studied countries, salaries for English speakers versus non-English speakers were around 25\% higher. This is a major incentive for individuals to improve their English, and it is broadly accepted in each country that strong language skills lead to economic prosperity and individual wealth".

In terms of job potential and career focus; for example, an obvious career path that relies on strong foreign language skills is translation and interpretation. With the globalization of businesses and populations growing increasingly cosmopolitan, the need for a transactional knowledge of languages has become very important in both private and government sectors. According to Bureau of Labor Statistics (2014-15), employment of interpreters and translators is projected to grow 29 percent from 2014 to 2024, much faster than the average for all occupations. Employment growth will be driven by increasing globalization and by large increases in the number of non-English-speaking people in the United States. Job prospects should be best for those who have professional certification. For example, countries that receive people of different linguistic origins converging for medical treatment require hospitals and health organizations to provide language interpreting and translation services. Regardless of which career path is pursued, studying a foreign language can also help with some of the intangible skills that are critical to success in one's professional, and personal life including: 
strong analytic skills, an appreciation for different perspectives, and deep cultural awareness and sensitivity. For example, the Palestinian economy is expected to depend largely on tourism as one of the main national income. This is to substantiate a rationale in relating foreign languages to the total development of developing countries.

Currently, Palestine has thousands of NGOs and projects which involve foreign funders; therefore, the tasks revolve around interactional needs and writing tasks pertaining to transactions which are language-based.

Students that graduate from English language departments in Palestine look forward to working in fields that are related to their qualifications and skills. The current English Language and Literature undergraduate programs in the Palestinian universities are assumed to be timeworn due to feedback from the work place which ushers to inability to satisfy the language tasks given to them.

\section{MeThodology}

The methodology by which data have been collected is a questionnaire consisting of four main sections. The targeted population is seniors in Palestinian English language departments who are expected to graduate in the upcoming semester of 2014-2015. The sample was a total of 45 English language students from three Palestinian universities, namely, Al-Quds University, Birzeit University, and Bethlehem University. The sample was restricted to students from the West Bank's universities; therefore, universities in Gaza Strip were not included simply due to mobility reasons.

The ultimate goal of the foreign language programs is to graduate skilled persons who possess a general language proficiency; therefore, it behooves educators and other stakeholders to reconsider and reassess these programs to examine whether or not they meet the objectives based on research findings. Hence, we conducted this research to examine seniors' expectations about the potential careers by eliciting the expected careers in the Palestinian market place, and the regional and international ones. Moreover, we endeavor to approach a deeper understanding of how learning foreign languages contributes to the improvement of individuals and their chances to advance professionally and to satisfy job needs. Accordingly, educators would adjust the English language programs to meet the needs of the market place. The research main question is: in what sectors do English language graduates expect to be hired after graduation. However, the first part will reveal their expectations of the jobs they might take up upon graduation. Another part of the research is expected to reveal whether the English language graduates are more desirable for employers, having better chances competing in the market force and the current personal functions the one they foresee in the future. A fourth part reveals the other e-uses that contribute to individuals' development.

\section{RESUltS}

Research main question: when seniors were asked about their expectations of future job opportunities, they answered as follow:

In response to their expectations of their future careers, respondents (as shown in Figure 1) ranked non-governmental organizations (NGOs) as the most potential sector they expect to join after graduation with around $60 \%$ believing that they have high chances while $27 \%$ have moderate chances. The underlying reason behind their choice is that Palestine hosts many NGOs that depend mainly on foreign funders. However, interpreting and translation career holds the second place since the Palestinian market is directly engaged to foreign markets for the purpose of importation with 73\% having high and moderate expectations to be hired in that sector. Another reason why translation is highly needed is that NGOs ask for different translation and interpreting tasks. Consulates, representatives and other governmental and nongovernmental bodies keep asking for translators. Teaching, appearing in the third place with around $70 \%$ having high and moderate expectations, which is considered to be a potential career for many graduates for English as it is a compulsory subject in schools. Tourism and public relation officers were in the fourth rank but with around $75 \%$ believing that they have high and moderate chances with "the high" is leveling with the "moderate" expectations. Media, banks and business are ranking the lowest. 


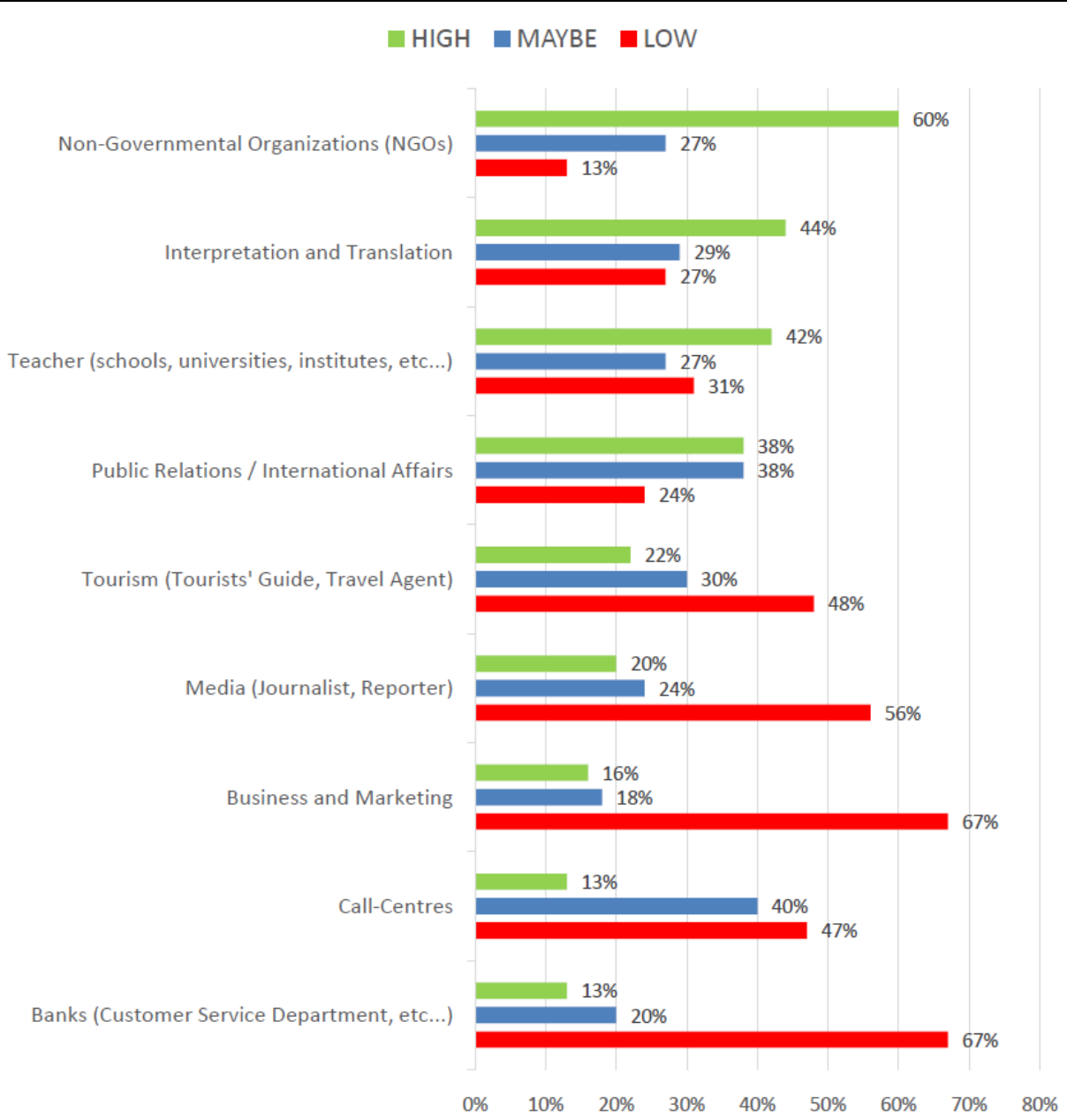

Figure1. English Language Job Opportunities

Sub question1: when seniors were asked about if they expect to have privileges and benefits endowed by the English language skills, their responses were as follow:

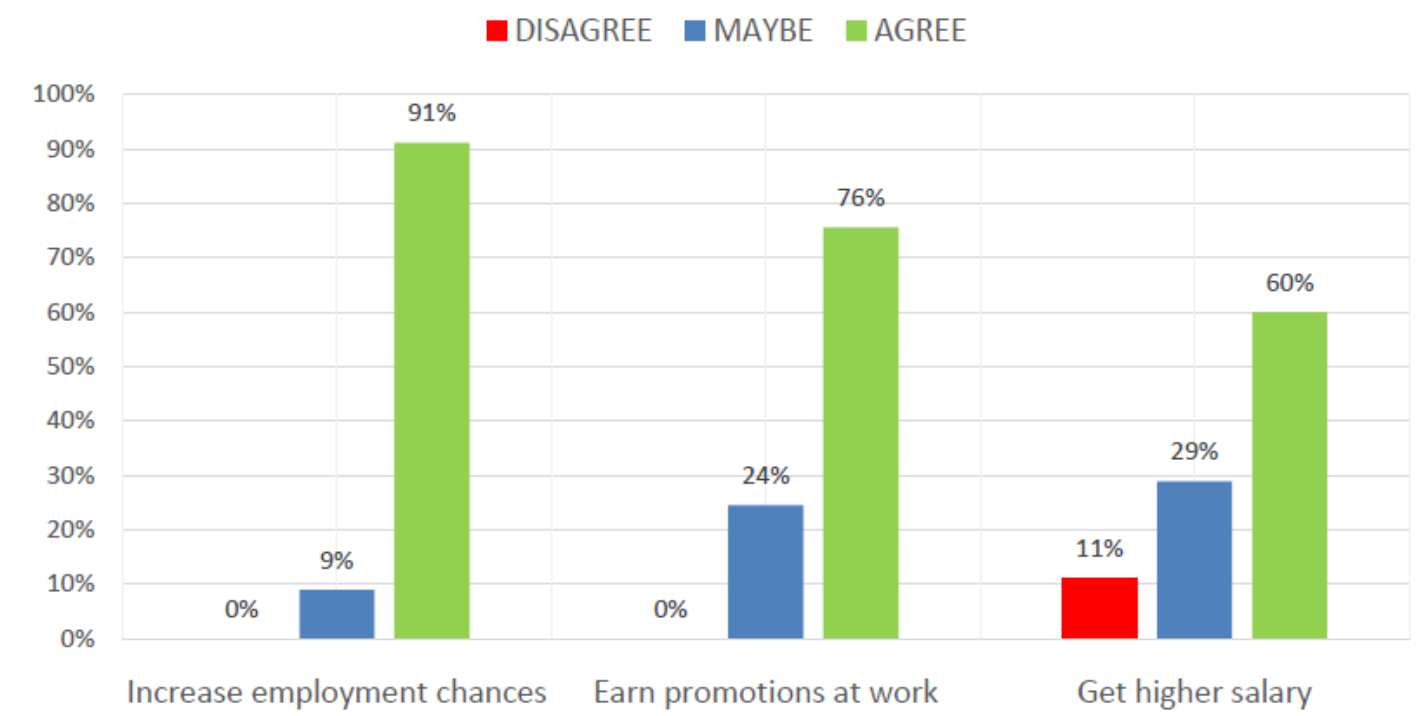

Figure2. Privileges of Having English Language

Respondents said that they expect to be privileged for being skilled in English. They believe that their skills in English language increase their employment chances compared to those who lack these skills; actually $91 \%$ of them agreed with this statement. Moreover, being skilled in English language will allow them to compete with their colleagues in their favor in earning faster promotions with $76 \%$ agreeing, and they expect to receive higher salaries with $60 \%$ of approving this expectation with high expectations. 
English Language Skills and Job Opportunities, Privileges, Personal Functions and E-Uses as Perceived by Seniors in Palestinian Universities

Subquestion2: what other personal functions for which seniors are using their language skills are.

- HIGH MODERATE $\square$ LITTLE

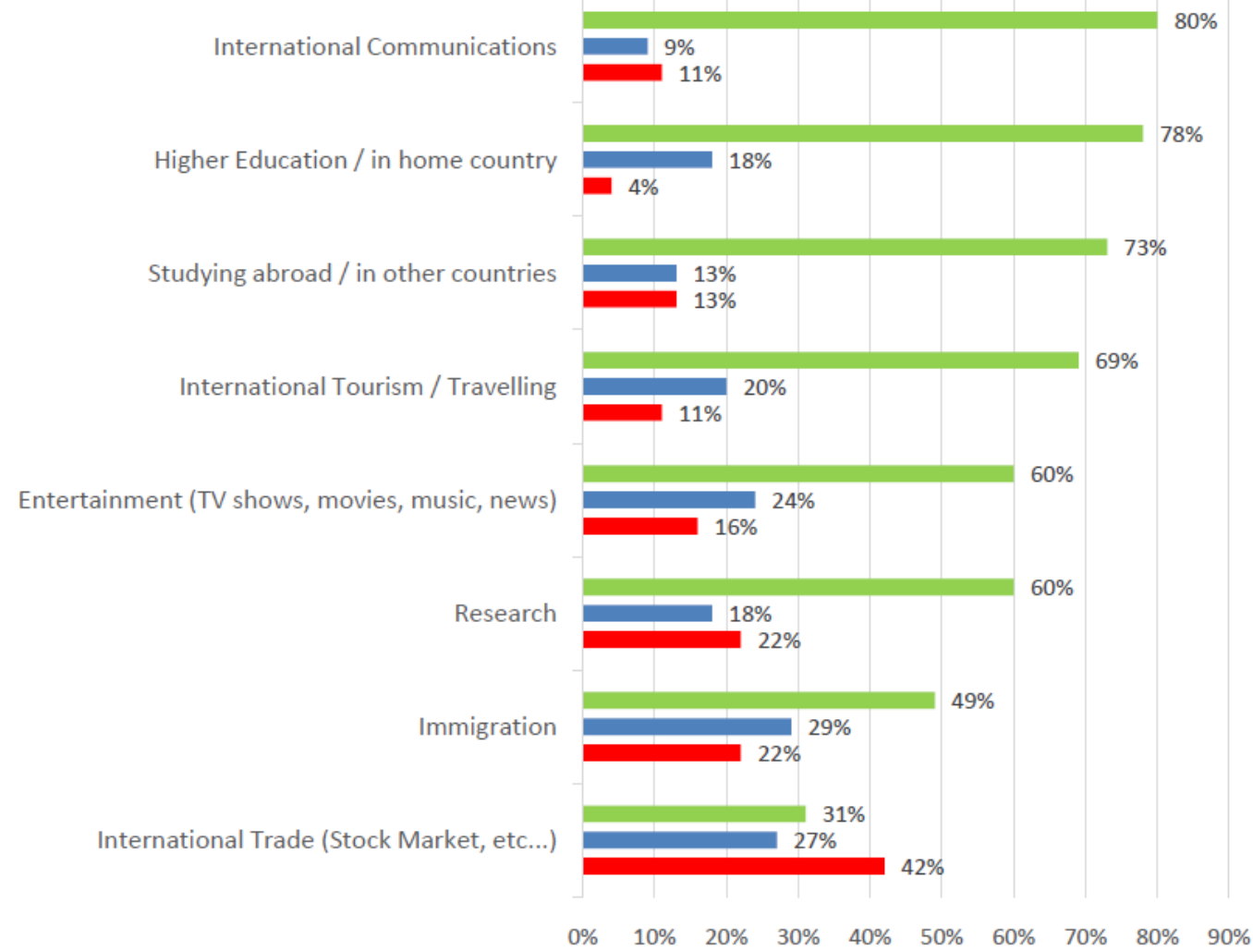

Figure3. Other Personal Functions of English Language

Respondents said that the English language skills are crucial in the first place for international communications with $90 \%$ expect this future function. In the second place, believing a vital it is important for "Higher Education" in their home country with $78 \%$ of them believe of high chances of future need knowing that, in Palestine, English is the medium of instructions for all science related, and business programs. Appearing in the third place, with $73 \%$ expressing high expectation, is "pursuing graduate programs in foreign countries" which is known to require a good command of English; moreover, the English language is a very useful language to acquire when it comes to tourism and travelling, entertainment and research with 60-70\%, again expressing high expectations. English language is the language of technology, science, and other fields of study; hence, it is the language of research by which people worldwide exchange knowledge.

Sub question 3: how frequent do students employ their foreign language for e-uses:

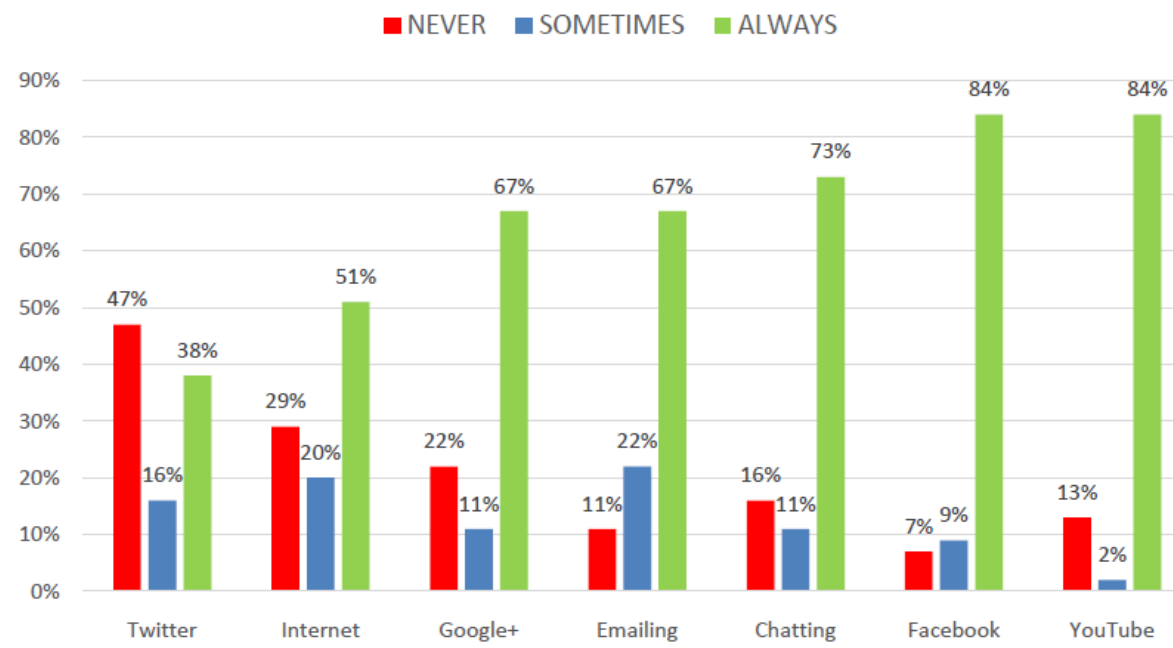

Figure4. English Language and Personal e-Uses 
The need of English language for both local and international communications was demonstrated in their use of it for social media and other purposes, particularly Facebook and YouTube with 84\% showing continual use of these two types. Chatting comes in the third position with $73 \%$. Respondents said that they use English language in chatting, emailing and goggling with family members, friends, and acquaintances on social media websites and other mobile applications, such as WhatsApp with $60-73 \%$ also indicate their frequent use for these purposes.

\section{DisCuSSION AND CONCLUSION}

Senior's responses show that the fields in which they expect to be enrolled upon graduation require them to be highly skilled in the English language. Working in non-governmental organizations, which depend heavily on foreign subsidies, demand specific skills such as writing fundraising proposals, extended reports, letters, and CVs, and the ability to communicate orally with funders are subtle requirements of these positions. Working as interpreters and/or translators require graduates to master the language in-use fully in order to cope with job requirements indicating focus on the first language competency. They need to be exposed to authentic syllabuses which involve materials that are related to business, tourism, communication, and so forth to acquire useful vocabulary through authentic contexts. This requires English for Specific Purposes (ESP) courses to be infused in their English language undergraduate program replacing the classical literary components prevailing in English as a foreign language undergraduate program in Palestine. Becoming a teacher is a desirable job for a proportion of graduates, yet it requires applied linguistics qualifications. Students who look forward to becoming teachers, whether for primary, secondary, or tertiary levels, need to be aware of teaching and learning techniques and strategies, activities and approaches, and other pedagogical aspects in order to succeed in the teaching profession. Public relations and international affairs are sectors in which graduates expect to work as well. These two sectors demand qualified employees whose abilities in speaking and writing are expected to be high, and cross-cultural emphasizing cultural differences aspects. Sectors in which seniors expect to be hired demand a general language proficiency, and this is the responsibility of all English language departments in the Palestinian universities to offer for their graduates.

\section{RECOMMENDATIONS}

Projecting on the results, one can sense the huge gap between what is taught in the English undergraduate programs in the Palestinian universities and market needs. Hence, the researcher strongly recommends:

1. Replacing classical literature courses with others that are related to communication skills such as, speaking and writing; therefore, graduates would have better chances to advance professionally in their future jobs.

2. Including English for Specific Purposes (ESP) such as business English courses satisfy nongovernmental organizations functions, such as writing fundraising proposals, extended reports, letters, CVs.

3. Redesigning English language programs to meet the needs of the market place. For example, offering more courses that are related to applied linguistics contributes to the enhancement of teaching skills for those who are looking forward to becoming teachers.

\section{REFERENCES}

[1] The World Commission on Environment and Development (WCED), Our Common Future, 41 (1987). (Report)21-41

[2] André Sapir, Philippe Aghion, Giuseppe Bertola, Martin Hellwig,Jean Pisani-Ferry, DariuszRosati, José Viñals\&Helen Wallace, An Agenda for A Growing Europe: Making the EU Economic System Deliver, 21-41 (2003). (A report of an independent high-level study groupestablished on the initiative of thePresident of the European Commission)

[3] Scherer, F and K. Hue, Top Managers' Education and R\&D Investment, Research Policy, 21, 507-511 (1992). (Research paper)

[4] Krueger, Alan and Mikael Lindahl, Education for Growth: Why and for Whom?,Journal of Economic Literature, 1130 (2001)

[5] Nelson, Richard, and Edmund Phelps, Investment in Humans, Technological Diffusion and Economic Growth, 69-75 (1966). 
[6] Economist Intelligence Unit, Competing Across Boarders: How Cultural and Communication Barriers Affect Business, 16 (2012). (Report)

[7] Pinon, Robert and Jon Haydon, The Benefits of the English Language for Individuals and Societies: Quantitative Indicators from Cameroon, Nigeria, Rwanda, Bangladesh and Pakistan, 7 (2010). (A custom report compiled by Euromonitor International for the British Council)

[8] Bureau of Labor Statistics, U.S. Department of Labor, Occupational Outlook Handbook, 201415 Edition, Interpreters and Translators, on the Internet at http://www.bls.gov/ooh/media-andcommunication/interpreters-and-translators.htm (visited April 17, 2015).

\section{AUTHOR's BIOGRAPHY}

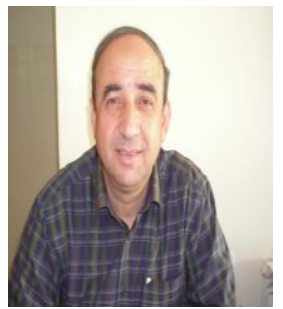

Omar Abu Humos, Ph.D., is a university assistant professor at Alquds University Department of English; He holds a Ph.D. from the University of San FranciscoSchool of Education with emphasis on second language acquisition. He assumed the position of the chair of the English Department twice and the director of the language center also twice in addition to the position of a dean of the university requirement program.

He currently teaches linguistics courses in addition to Applied linguistics, language research, writing and language skills course. He also teaches language Education courses for Masters program for English teacher at an American College at Alquds University.

Dr. Omar was seconded to the Ministry of Education to supervise the implementation of the first Palestinian curricula project (1998-2006) and to participate in developing and designing the first Palestinian English curricula, Textbooks and syllabus, for the whole public school system from grade one to grade twelve.

He has also participated in international programmes as an external expert, amongst which the UNICEF-led regional conference on 'Quality Education through Quality Curricula' held in Cairo/Egypt (2003). He is an IBE UNESCO consultant and resource person for the UNESCO Programme on curriculum. Lately, he represented UNESCO as a trainer in Asian countries and with the World bank in African countries. 